\title{
RESEARCH
}

Open Access

\section{Elevated circulating TGF $\beta 1$ during acute liver failure activates TGF $\beta R 2$ on cortical neurons and exacerbates neuroinflammation and hepatic encephalopathy in mice}

\author{
Matthew McMillin 1,2,4, Stephanie Grant ${ }^{1,2,3}$, Gabriel Frampton ${ }^{1,2,4}$, Anca D. Petrescu1,2,3, Elaina Williams ${ }^{1,2,3}$, \\ Brandi Jefferson ${ }^{1,2}$, Alison Thomas ${ }^{2}$, Ankita Brahmaroutu ${ }^{2}$ and Sharon DeMorrow ${ }^{1,2,3,4^{*}}$ (D)
}

\begin{abstract}
Background: Acute liver failure resulting from drug-induced liver injury can lead to the development of neurological complications called hepatic encephalopathy (HE). Hepatic transforming growth factor beta 1 (TGF $\beta 1$ ) is upregulated due to liver failure in mice and inhibiting circulating TGF $\beta$ reduced HE progression. However, the specific contributions of TGF $\beta 1$ on brain cell populations and neuroinflammation during HE are not known. Therefore, the aim of this study was to characterize hepatic and brain TGF $\beta 1$ signaling during acute liver failure and its contribution to HE progression using a combination of pharmacological and genetic approaches.
\end{abstract}

Methods: $\mathrm{C57BI/6}$ or neuron-specific transforming growth factor beta receptor 2 (TGF $\beta 2$ 2) null mice (TGF $\beta R 2^{\triangle \mathrm{Neu}}$ ) were treated with azoxymethane (AOM) to induce acute liver failure and HE. The activity of circulating TGF $\beta 1$ was inhibited in C57BI/6 mice via injection of a neutralizing antibody against TGF $\beta 1$ (anti-TGF $\beta 1$ ) prior to AOM injection. In all mouse treatment groups, liver damage, neuroinflammation, and neurological deficits were assessed. Inflammatory signaling between neurons and microglia were investigated in in vitro studies through the use of pharmacological inhibitors of TGF $\beta 1$ signaling in HT-22 and EOC-20 cells.

Results: TGF $\beta 1$ was expressed and upregulated in the liver following AOM injection. Pharmacological inhibition of TGF $\beta 1$ after AOM injection attenuated neurological decline, microglia activation, and neuroinflammation with no significant changes in liver damage. TGF $\beta R 2^{\triangle N e u}$ mice administered $A O M$ showed no effect on liver pathology but significantly reduced neurological decline compared to control mice. Microglia activation and neuroinflammation were attenuated in mice with pharmacological inhibition of TGF $\beta 1$ or in TGF $\beta R 2^{\triangle \text { Neu }}$ mice. TGF $\beta 1$ increased chemokine ligand 2 (CCL2) and decreased C-X3-C motif ligand 1 (CX3CL1) expression in HT-22 cells and reduced interleukin-1 beta (IL-1ß) expression, tumor necrosis factor alpha (TNFa) expression, and phagocytosis activity in EOC-20 cells.

Conclusion: Increased circulating TGF $\beta 1$ following acute liver failure results in activation of neuronal TGF $\beta$ R2 signaling, driving neuroinflammation and neurological decline during AOM-induced HE.

Keywords: Acute liver failure, Azoxymethane, Microglia, Neuroinflammation, Necrosis

\footnotetext{
* Correspondence: sharon.demorrow@austin.utexas.edu

${ }^{1}$ Central Texas Veterans Health Care System, Temple, TX, USA

${ }^{2}$ Department of Medical Physiology, College of Medicine, Texas A\&M

University Health Science Center, Temple, TX, USA

Full list of author information is available at the end of the article
}

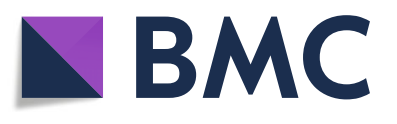

(c) The Author(s). 2019 Open Access This article is distributed under the terms of the Creative Commons Attribution 4.0 International License (http://creativecommons.org/licenses/by/4.0/), which permits unrestricted use, distribution, and reproduction in any medium, provided you give appropriate credit to the original author(s) and the source, provide a link to the Creative Commons license, and indicate if changes were made. The Creative Commons Public Domain Dedication waiver (http://creativecommons.org/publicdomain/zero/1.0/) applies to the data made available in this article, unless otherwise stated. 


\section{Background}

Drug-induced hepatotoxicity is a common cause of liver injury accounting for approximately one-half of the cases of acute liver failure [1]. The predominant extrahepatic complication of acute liver failure is the development of hepatic encephalopathy (HE), which can be defined as a brain dysfunction caused by liver insufficiency, manifesting as a wide spectrum of neurological or psychiatric abnormalities ranging from subclinical alterations to coma [2]. During acute liver failure, mortality is relatively high due to unpredictable systemic complications, with $20-25 \%$ of mortality resulting from increased intracranial pressure and the development of HE [3]. Therefore, strategies to manage symptoms of HE could prove beneficial in improving the overall survival rate of patients with acute liver failure. The increase in circulating and neural ammonia concentrations in $\mathrm{HE}$ promotes neurobehavioral changes like cerebral edema, astrocyte swelling, and dysregulation of numerous neurotransmitter systems [4]. Ammonia alone cannot explain all the neurobehavioral changes observed during HE. In animal models, arterial ammonia levels do not always correlate with the severity of the HE as neurological deficits can be observed prior to significant elevations of ammonia [5]. In addition, seizures can be associated with hyperammonemia but are not commonly observed in HE patients [6]. That being said, it is thought that hyperammonemia may be working in conjunction with neuroinflammation to cause the symptoms of $\mathrm{HE}[7,8]$. Indeed, it has been shown that microglia activation is observed in patients with acute liver failure [9]. We have demonstrated that activation of microglia occurs during $\mathrm{HE}$ in mice, and this is a result of increased chemokine ligand 2 (CCL2) and decreased chemokine (C-X3-C motif) ligand 1 (CX3CL1) expression in neurons, which has the combined effect of promoting microglia activation and neuroinflammation [10, 11]. Together, increased systemic inflammation and circulating inflammatory molecules observed during liver damage can contribute to neuroinflammation and the induction of encephalopathy.

Transforming growth factor beta (TGF $\beta$ ) is a multifunctional family of cytokines consisting of 4 main proteins (TGF $\beta 1-4)$. TGF $\beta$ binds to and activates a receptor complex comprising TGF $\beta$ receptor 1 and TGF $\beta$ receptor 2 (TGFßR2), to induce signal transduction pathways including SMAD-2/3. We have recently demonstrated that TGF $\beta 1$ is increased in the serum of mice with acute liver injury [12] and that this increased circulating TGF $\beta 1$ contributes to the pathological hyperpermeability of the blood-brain barrier that occurs in the development of HE [13]. Systemic treatment of mice with a pan-TGF $\beta$ neutralizing antibody had minimal effects on liver damage, but attenuated the development of HE [12], although the precise identity of the TGF $\beta$ family member responsible for these effects has not been defined. While we have demonstrated that there was increased TGF $\beta 1$ protein content and activation of downstream effectors of the TGF $\beta$ pathway in the brain after the development of $\mathrm{HE}$, there was not a concomitant increase in TGF $\beta 1$ mRNA expression in the brain [12], suggesting that TGF $\beta 1$ is coming from an extracranial source.

The aims of this study were to determine if a more specific neutralizing antibody against TGF $\beta 1$ could attenuate neuroinflammation and the neurological complications of acute liver failure and to clearly delineate the role of TGF $\beta 1$ signaling in neuroinflammation and the development of HE using tissue-specific knockout mice and in vitro cell culture studies.

\section{Methods}

\section{Azoxymethane model of acute liver failure}

Floxed TGF $\beta R 2$ mice (TGF $\beta R 2^{\mathrm{fl} / \mathrm{fl}}$, stock \# 012603; Tgfbr2 ${ }^{\text {tm1Karl }}$ ) from The Jackson Laboratory (Bar Harbor, ME) were crossed with Thy1-cre mice (stock \# 007606; $\operatorname{Tg}$ (Thy1-cre/ERT2,-EYFP)AGfng) to generate a neuron TGF $\beta R 2$ null mouse (TGF $\beta R 2^{\triangle \mathrm{Neu}}$ ). In vivo experiments were performed using male C57Bl/6 (TGF $\beta R 2^{\text {wt } / \text { wt }}, 25-30$ g; Charles River Laboratories, Wilmington, MA) or TGF $\beta R 2^{\triangle \mathrm{Neu}}$ mice. C57Bl/6 mice (TGF $\beta R 2^{\mathrm{wt} / \mathrm{wt}}$ ) were used as control mice after validation by assessing $\mathrm{HE}$ progression and time to reach coma in TGF $\beta R 2^{\mathrm{wt} / \mathrm{wt}}, \mathrm{TGF} \beta \mathrm{R} 2^{\mathrm{l} / \mathrm{fl}}$, and TGF $\beta R 2^{\Delta N e u}$ mice (see Additional file 1: Supplementary Materials and Methods). In addition, a methodology for genotyping and confirmation of TGF $\beta R 2$ knockout in TGF $\beta R 2^{\triangle \mathrm{Neu}}$ mice is provided in Additional file 1: Supplementary Materials and Methods.

Acute liver failure and HE were induced via a single intraperitoneal injection of $100 \mathrm{mg} / \mathrm{kg}$ of azoxymethane (AOM) into mice as described previously [14-17]. In a sub-group of mice, neutralizing antibodies against TGF $\beta 1$ (anti-TGF 11 ) (MAB240, R\&D Systems, Minneapolis, MN) or immunoglobulin G1 (IgG1) (R\&D Systems) were injected at $1 \mathrm{mg} / \mathrm{kg}$ into the peritoneum $1 \mathrm{~h}$ prior to AOM injection. Mice were injected with anti-TGF $\beta 1$ or IgG1 prior to AOM to ensure that TGF $\beta 1$ expression was not increased and no liver damage was present as a substantial liver injury is observed a few hours after AOM injection $[5,18]$. For TGF $\beta R 2^{\triangle \mathrm{Neu}}$ mice, tamoxifen was injected into the peritoneum $(0.125 \mathrm{mg} / \mathrm{g} /$ day for 3 days $)$ prior to AOM injection with the last tamoxifen injection coming at $6 \mathrm{~h}$ after $\mathrm{AOM}$ injection. After AOM injection, mice were placed on heating pads set to $37^{\circ} \mathrm{C}$ to ensure they remained normothermic. Hydrogel and rodent chow were placed on cage floors to ensure access to food and hydration. After $12 \mathrm{~h}$ and every $4 \mathrm{~h}$ thereafter, mice were injected subcutaneously with $5 \%$ dextrose in $250 \mu \mathrm{L}$ saline to ensure euglycemia and hydration. Following injection, 
mice were monitored at least every $2 \mathrm{~h}$ (starting at $12 \mathrm{~h}$ post-AOM injection) for body temperature, weight, and neurological score using previously published methodology $[10,12,19]$. Once neurological impairment was evident, mice were continuously monitored with formal assessments of temperature, body weight, and neurological score performed each hour. The neurological score was assessed by an investigator blind to the treatments by assigning a score between 0 (absent) and 2 (intact) to each of the following parameters: the pinna reflex, corneal reflex, tail flexion, escape response, righting reflex, and ataxia. The summation of these six reflexes gives a neurological score between 0 and 12 .

In a subset of AOM-treated mice, tissue was collected prior to neurological symptoms (pre-neurological), when minor ataxia and weakened reflexes were present (minor neurological) and when major ataxia and deficits in reflexes were evident (major neurological) as described previously $[10,20]$. For all other mouse experiments, the endpoint was when mice lost their corneal and righting reflex, at which point the time to coma was recorded, the mice were euthanized, and tissue was collected.

\section{Cell culture}

The HT-22 mouse hippocampal neuron cell line was provided by Dr. David Schubert (The Salk Institute, La Jolla, CA) and cultured using established protocols [21, 22]. HT-22 cells were treated with recombinant mouse TGF $\beta 1$ $(0.5 \mathrm{ng} / \mathrm{ml}), \mathrm{GW} 788388(1 \mu \mathrm{M})$, or SIS3 $(10 \mu \mathrm{M})$. After 24 $\mathrm{h}$, conditioned media was collected and cells were lysed for RNA isolation for subsequent RT-PCR assays.

A commercially available mouse microglia cell line (EOC-20) was purchased and cultured according to ATCC guidelines (Manassas, VA). Cells were plated onto 12 -well plates and allowed to adhere overnight. After the cells were confluent, media was removed and replaced with conditioned media from HT-22 cells treated as outlined above. In addition, EOC-20 cells that were supplemented with HT-22 cell conditioned media were treated with $\mathrm{C} 021$ dihydrochloride (C021) $(1 \mu \mathrm{M})$, INCB 3284 dimesylate (INCB) $(100 \mathrm{nM})$, or mouse soluble CX3CL1 $(1 \mu \mathrm{g} / \mathrm{ml})$. After $24 \mathrm{~h}$, cells were lysed for RNA isolation and subsequent RT-PCR experiments.

\section{Phagocytosis assay}

In EOC-20 cells, a Vybrant ${ }^{\mathrm{Tm}}$ Phagocytosis Assay Kit (Molecular Probes, Eugene, OR) was used according to the manufacturer's protocols. EOC-20 cells were plated into black 96-well cell culture plates at 10,000 cells per well and allowed to adhere overnight. Cell culture media was then removed and replaced with $100 \mu \mathrm{l}$ conditioned media from HT-22 cells and subsequently treated with $\mathrm{C} 021$, INCB, or mouse soluble CX3CL1 for $16 \mathrm{~h}$. Fluorescent E. coli bioparticles were resuspended in HBSS to a concentration of $1 \mathrm{mg} / \mathrm{ml}$, and $50 \mu \mathrm{l}$ was added to each well for $2 \mathrm{~h}$ at $37^{\circ} \mathrm{C}$. The conditioned media and fluorescent E. coli bioparticles were aspirated and fluorescence of $E$. coli bioparticles that did not undergo phagocytosis was quenched by adding $50 \mu \mathrm{l}$ of trypan blue $(0.125 \mathrm{mg} /$ $\mathrm{ml}$ ) per well. Trypan blue was aspirated, and fluorescence of internalized $E$. coli bioparticles was read at $480 \mathrm{~nm}$ excitation and $520 \mathrm{~nm}$ emission.

\section{Immunofluorescence}

Frozen liver sections were cut into $8-\mu \mathrm{m}$ sections and mounted onto positively charged slides. Liver sections were blocked with $5 \%$ goat serum and incubated with antibodies against TGF $\beta 1$ (Abcam, Cambridge, MA) or CK8 (Santa Cruz Biotechnology, Dallas, TX). Fluorescent secondary antibodies labeled with Dylight 488 and Cy3 (Jackson ImmunoResearch Laboratories Inc., West Grove, PA) were used, and the slides were counterstained with ProLong® Gold Antifade Reagent containing 4',6-diamidino-2-phenylindole (DAPI) (ThermoFisher Scientific, Waltham, MA).

Free-floating immunofluorescence staining was performed on $30-\mu \mathrm{m}$ brain sections. Brain sections were blocked with $5 \%$ goat serum and were subsequently incubated with antibodies against IBA1 (Wako Chemicals USA, Richmond, VA) to detect morphology and relative staining of microglia. Immunoreactivity was visualized using fluorescent secondary antibodies labeled with Cy3. Brain sections were then subsequently moved to positively charged slides and had coverslips mounted using ProLong $\subset$ Gold Antifade Reagent containing DAPI.

Liver and brain sections were viewed and imaged using a Leica TCS SP5-X inverted confocal microscope (Leica Microsystems, Buffalo Grove, IL). Field fluorescence area of IBA-1 was determined by converting images to grayscale, inverting their color and quantifying field staining intensity with ImageJ software.

\section{Gene expression analyses}

RNA was extracted from cell culture lysates or liver tissue using a RNeasy Mini Kit (Qiagen, Germantown, $\mathrm{MD)}$ according to the manufacturer's instructions. Synthesis of cDNA was accomplished using a Bio-Rad iScript $^{\mathrm{TM}}$ cDNA Synthesis Kit (Hercules, CA). RT-PCR was performed as previously described [23] using commercially available primers designed against mouse TGF $\beta 1$, CCL2, CX3CL1, interleukin-1 beta (IL-1 $\beta$ ), tumor necrosis factor alpha (TNF $\alpha$ ), and glyceraldehyde 3-phosphate dehydrogenase (GAPDH) (SABiosciences, Frederick, MD). A $\triangle \Delta C T$ analysis was performed using vehicle-treated tissue or untreated primary neurons as controls for subsequent experiments [24, 25]. 


\section{A}
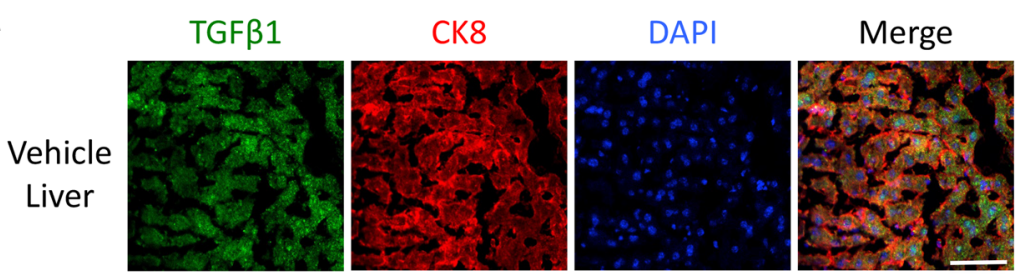

B
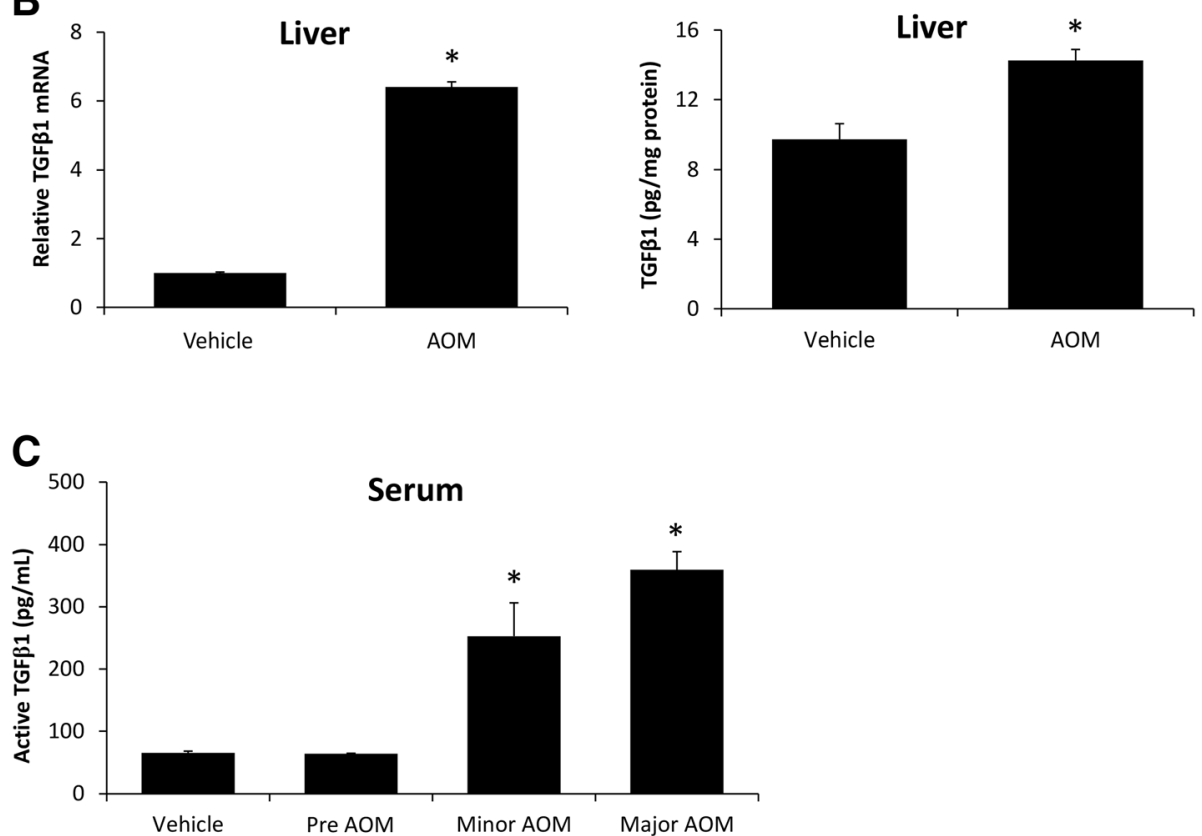

Fig. 1 Hepatic TGF $\beta 1$ is increased during AOM-induced HE. a Immunofluorescence for TGF $\beta 1$ (green) and CK8 (red) in mice injected with saline. Scale bar indicates $50 \mu \mathrm{M}$. b Relative TGF $\beta 1$ mRNA expression in the livers from vehicle- and AOM-treated mice. c Concentration of active TGF $\beta 1$ levels in liver homogenates normalized by total protein concentration in vehicle and AOM-treated mice. $\mathbf{d}$ Serum active TGF $\beta 1$ concentration measured in picograms per milliliter of serum from vehicle and AOM-treated time course mice. ${ }^{*} p<0.05$ compared to vehicle-treated mice. $n=3$ for TGF 1 mRNA analyses and $n=4$ for ELISA analyses

\section{Protein expression analyses}

Liver or cortex tissue was homogenized using a Miltenyi Biotec gentleMACS ${ }^{\mathrm{m}}$ Dissociator (San Diego, CA), and total protein was quantified using a ThermoFisher Pierce $^{\mathrm{m}}$ BCA Protein Assay kit (Waltham, MA). The ThermoFisher TGF $\beta 1$ ELISA kit was performed in tissue or serum according to manufacturer's instructions except the acid activation step was skipped to measure only bioactive TGF $\beta 1$ in our samples. For the Mouse Duoset CCL2, CX3CL1, IL-1 $\beta$, and TNF $\alpha$ ELISA kits (R\&D Systems), capture antibodies were incubated overnight in 96-well plates. After incubation, the assay was performed according to the instructions provided by $R \& D$ Systems. For each ELISA kit, the total input for each sample was $100 \mu \mathrm{g}$ of protein or $100 \mu \mathrm{L}$ of undiluted conditioned cell media. Absorbance was read using a SpectraMax ${ }^{\circ}$ M5 plate reader from Molecular Devices (Sunnyvale, CA). Data were reported as TGF $\beta 1$,
CCL2, CX3CL1, IL-1 $\beta$, or TNF $\alpha$ concentration per milliliter of serum, per milligram of total lysate protein or per milliliter of conditioned cell media.

\section{Liver histology and serum chemistry}

Paraffin-embedded livers were cut into 4- $\mu \mathrm{m}$ sections and mounted onto positively charged slides (VWR, Radnor, PA). Slides were deparaffinized and stained with Hematoxylin QS (Vector Laboratories, Burlingame, CA) followed by staining with eosin Y (Amresco, Solon, $\mathrm{OH}$ ) and rinsed in $95 \%$ ethanol. The slides were then dipped into $100 \%$ ethanol and subsequently through two xylene washes. Coverslips were mounted onto the slides using CytoSeal XYL mounting media (ThermoFisher). The slides were viewed and imaged using an Olympus BX40 microscope with an Olympus DP25 imaging system (Olympus, Center Valley, PA). All images are taken as $x$ 200 magnification. 


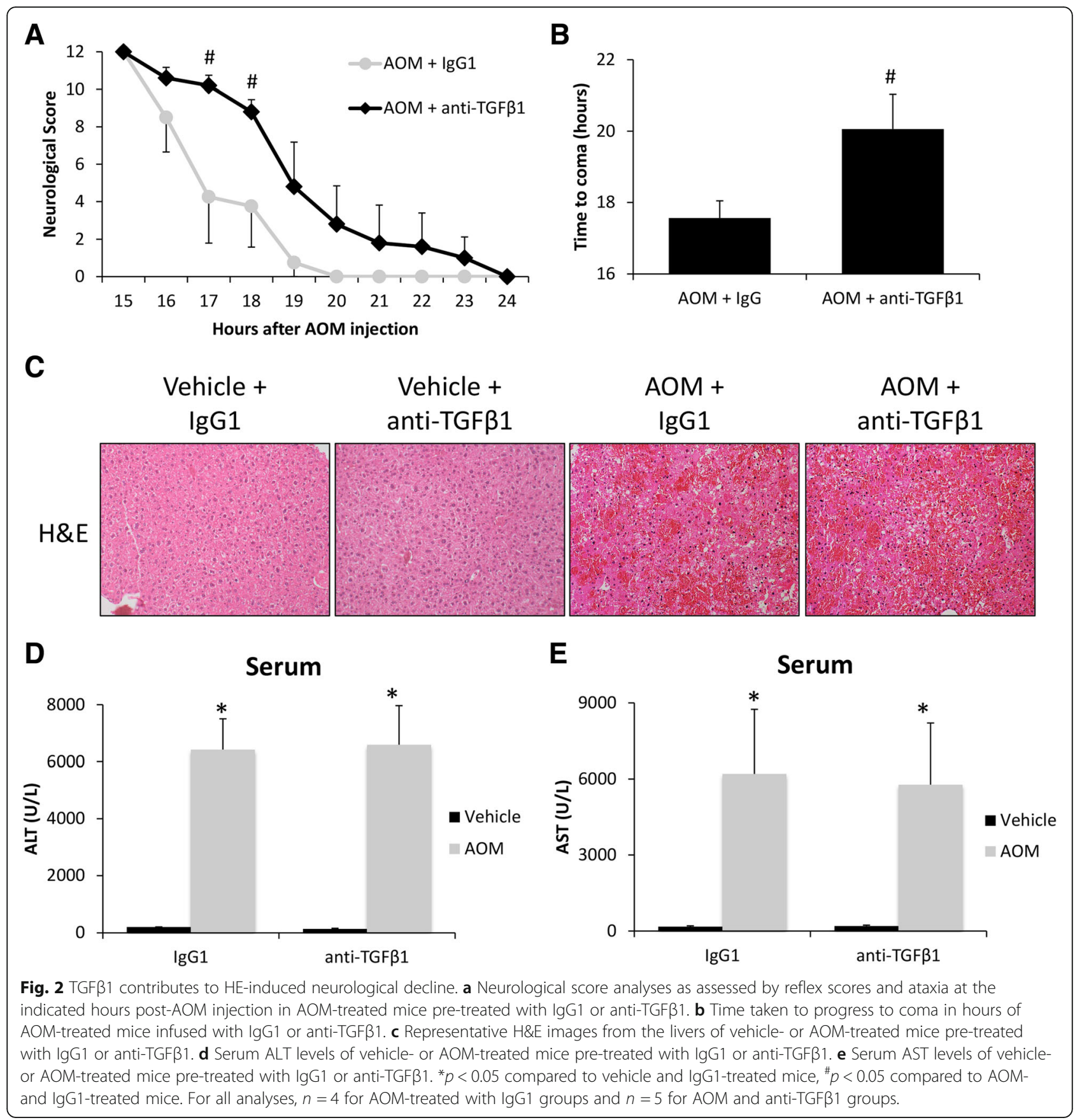

Liver function was assessed by measuring serum alanine aminotransferase (ALT) and aspartate aminotransferase (AST) levels using a Catalyst One serum chemistry analyzer from IDEXX Laboratories, Inc. (Westbrook, MA).

\section{Statistical analyses}

All statistical analyses were performed using GraphPad Prism software (GraphPad Software, La Jolla, CA). Results were expressed as mean $\pm \mathrm{SEM}$. For data that passed normality tests, significance was established using the Student $t$ test when differences between two groups were analyzed, and analysis of variance when differences between three or more groups were compared followed by an appropriate post hoc test. If tests for normality failed, two groups were compared with a Mann-Whitney $U$ test or a Kruskal-Wallis ranked analysis when more than two groups were analyzed. For the neurological score analyses, a two-way analysis of variance was performed followed by a Bonferroni multiple comparison post hoc 

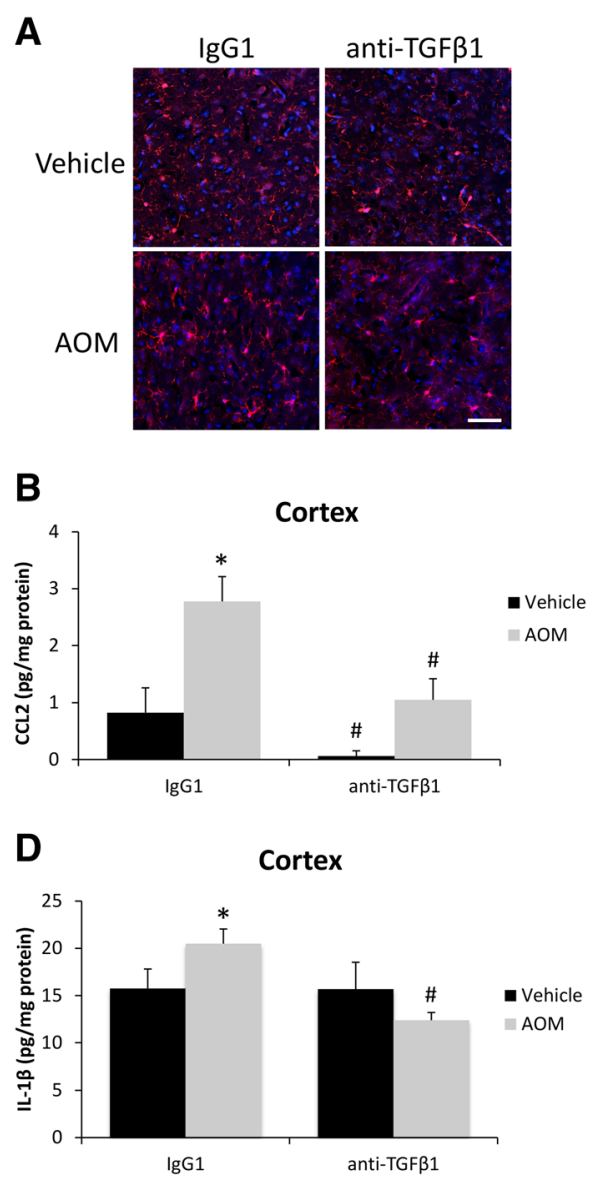
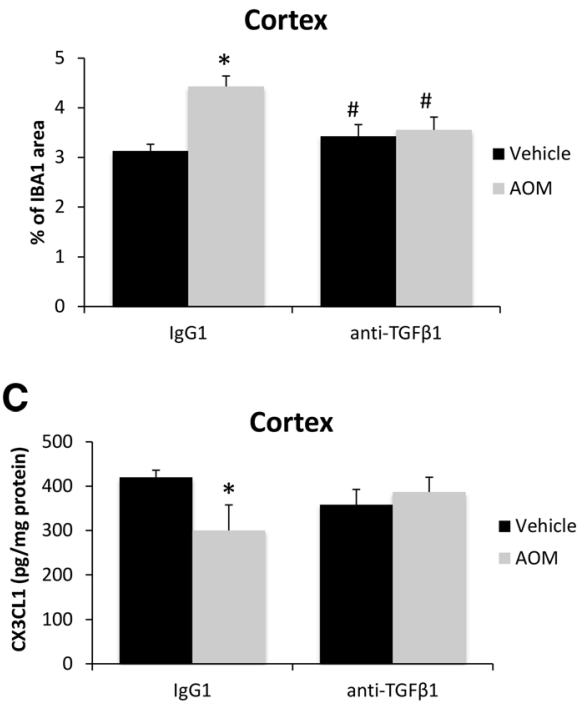

$\mathbf{E}$

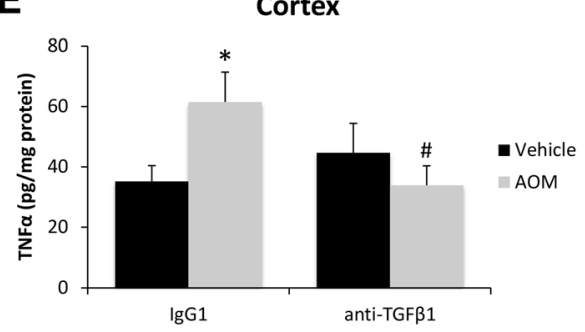

Fig. 3 TGF $\beta 1$ promotes microglia proliferation and neuroinflammation. a Representative staining and quantification for IBA1 (red) in the cortex from IgG1 or anti-TGF $\beta 1$ mice administered saline (vehicle) or AOM. DAPI (blue) was used to stain nuclei. Scale bar indicates $50 \mu M$. b CCL2 protein expression normalized by total protein concentration in the cortex of IgG1 or anti-TGF $\beta 1$ mice administered vehicle or AOM. c CX3CL1 protein expression normalized by total protein concentration in the cortex of IgG1 or anti-TGF $\beta 1$ mice administered vehicle or AOM. $\mathbf{d}$ IL-1 $\beta$ protein expression normalized by total protein concentration in the cortex of IgG1 or anti-TGF $\beta 1$ mice administered vehicle or AOM. e TNFa protein expression normalized by total protein concentration in the cortex of IgG1 or anti-TGF $\beta 1$ mice administered vehicle or $A O M$. ${ }^{*} p<0.05$ compared to vehicle- and IgG1-treated mice, ${ }^{\#} p<0.05$ compared to AOM- and IgG1-treated mice. $n=3$ for all analyses

test. Differences were considered significant for $p$ values less than 0.05 .

\section{Results}

\section{Hepatic TGF $\beta 1$ is increased during AOM-induced HE}

TGF $\beta 1$ cellular localization in the liver was determined using immunofluorescence, demonstrating that TGF $\beta 1$ was expressed in vehicle-treated liver and that its expression co-localized with the hepatocyte marker CK8 (Fig. 1a). In order to validate that TGF $\beta 1$ is increased during AOM-induced HE, TGF $\beta 1$ expression was assessed in the livers of vehicle- and AOM-treated mice. Hepatic TGF $\beta 1$ mRNA expression was significantly increased in AOMtreated mice compared to vehicle-treated mice (Fig. 1b). This result translated to a significant increase of active TGF $\beta 1$ levels in the liver of AOM-treated mice compared to vehicle-treated mice (Fig. 1c). Circulating levels of active TGF $\beta 1$ were significantly increased in AOM-treated mice at the minor and major stages of neurological decline in comparison to vehicle-treated mice (Fig. 1d).

\section{Neutralizing circulating TGF $\beta 1$ attenuates neurological decline and inflammation}

In order to determine the specific effects of TGF $\beta 1$ on the progression of AOM-induced HE, a neutralizing antibody against TGF $\beta 1$ (anti-TGF $\beta 1$ ) was injected into mice $1 \mathrm{~h}$ prior to vehicle or AOM injection. Pre-treatment with anti-TGF $\beta 1$ was found to significantly reduce the rate of neurological decline in AOM-treated mice compared to AOM-treated IgG1 controls $(p=0.0268)$ with significant differences between the two groups at $17 \mathrm{~h}$ and $18 \mathrm{~h}$ after AOM injection (Fig. 2a). Latency to reach coma in AOM-treated mice injected with anti-TGF $\beta 1$ was significantly greater compared to 

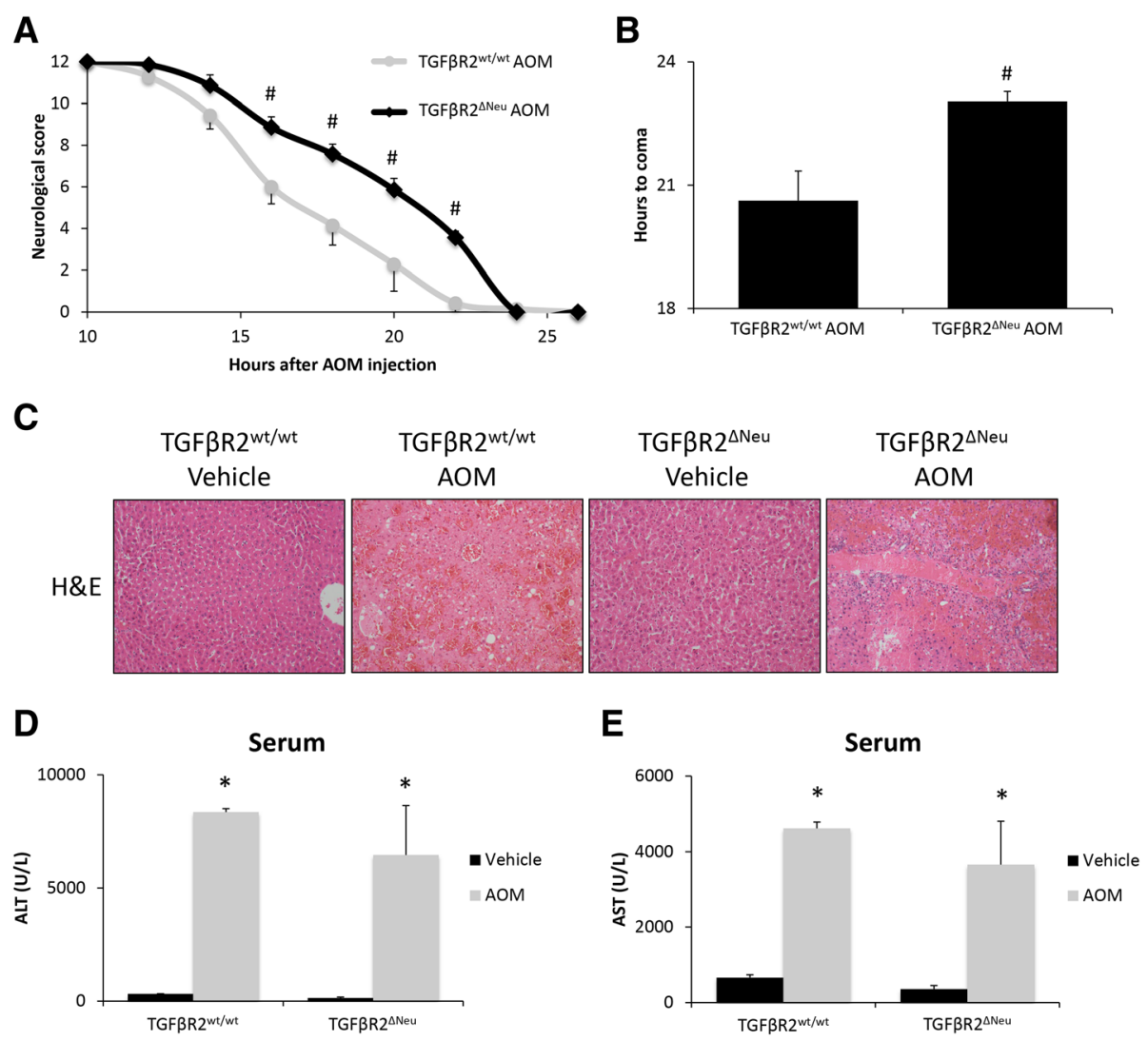

Fig. 4 Neuronal TGF $\beta R 2$ mediates AOM-induced neurological decline. a Neurological score analyses as assessed by reflex scores and ataxia at the indicated hours post-AOM injection in TGF $\beta R 2^{\text {wt/wt }}$ and TGF $\beta R 2^{\Delta \text { Neu }}$ mice. $\mathbf{b}$ Time taken to progress to coma in TGF $\beta R 2^{\text {wt }}{ }^{\text {wt }}$ and TGF $\beta R 2^{\triangle N \text { Neu }}$ mice administered AOM. c Representative H\&E images from the livers of TGF $\beta R 2^{\text {wt }}{ }^{\text {wt }}$ and TGF $\beta R 2^{\Delta \text { Neu }}$ mice administered vehicle or AOM. $\mathbf{d}$ Serum ALT levels of TGF $\beta R 2^{\text {wt }}{ }^{\text {wt }}$ and TGF $\beta R 2^{\Delta \text { Neu }}$ mice administered vehicle or AOM. e Serum AST levels of TGF $\beta R 2^{\text {wt } / \text { wt }}$ and TGF $\beta R 2^{\Delta \text { Neu }}{ }^{\text {mice administered vehicle or } A O M .}{ }^{*} p<0.05$ compared to TGF $\beta R 22^{\text {wt }}{ }^{\text {wt }}$ vehicle-treated mice, ${ }^{\#} p<0.05$ compared to TGF $\beta R 2^{\text {wt }}{ }^{\text {wt }}$ AOM-treated mice. $n=4$ for all analyses

IgG1-injected AOM-treated mice (Fig. 2b). This treatment had little effect on liver injury with significant hepatocyte necrosis and microvesicular steatosis observed in AOM-treated mice pretreated with anti-TGF $\beta 1$ or IgG1, and no apparent hepatic injury was observed in either vehicle group (Fig. 2c). In support of this finding, AOM treatment significantly increased the serum transaminases ALT (Fig. 2d) and AST (Fig. 2e) levels with no significant protection conferred by anti-TGF $\beta 1>$ pre-treatment.

As this treatment had little effect on the liver but reduced the rate of neurological decline, it is logical to conclude that anti-TGF $\beta 1$ treatment is primarily influencing the neurological aspects of HE. As previously described, inflammation is a significant contributor to $\mathrm{HE}$ progression, and therefore, we assessed neuroinflammation in these animal models. Microglia proliferation, as assessed by IBA1 staining, was significantly increased in the AOM-treated mice pre-treated with IgG1 but not in the AOM-treated mice pre-treated with anti-TGF $\beta 1$ (Fig. 3a). There was a significant increase of CCL2 protein in the cortex of AOM-treated mice with a significant reduction in the mice treated with anti-TGF $\beta 1$ (Fig. 3b). In addition, CX3CL1 was significantly reduced in the cortex of AOM-treated mice treated with IgG1 but not in AOM-treated mice injected with anti-TGF $\beta 1$ (Fig. 3c). The pro-inflammatory cytokines IL-1 $\beta$ (Fig. 3d) and TNF $\alpha$ (Fig. 3e) were significantly increased in the cortex of AOM-treated mice pre-treated with IgG1 but not in AOM-treated mice pre-treated with anti-TGF $\beta 1$. These data support that antagonizing circulating TGF $\beta 1$ reduces microglia proliferation and the subsequent pro-inflammatory response resulting in a reduction of neurological decline.

\section{Neuronal TGF $\beta R 2$ promotes neuroinflammation during $H E$}

We have previously demonstrated that TGF $\beta R 2$ is expressed in cortical neurons and therefore may be involved with TGF $\beta 1$-induced neuroinflammation [12]. AOM-treated TGF $\beta 2^{\triangle \mathrm{Neu}}$ mice had a significant reduction in their rate of neurological decline compared to AOM-treated TGF $\beta R 2^{\mathrm{wt} / \mathrm{wt}}$ mice $(p<0.0001)$ with 

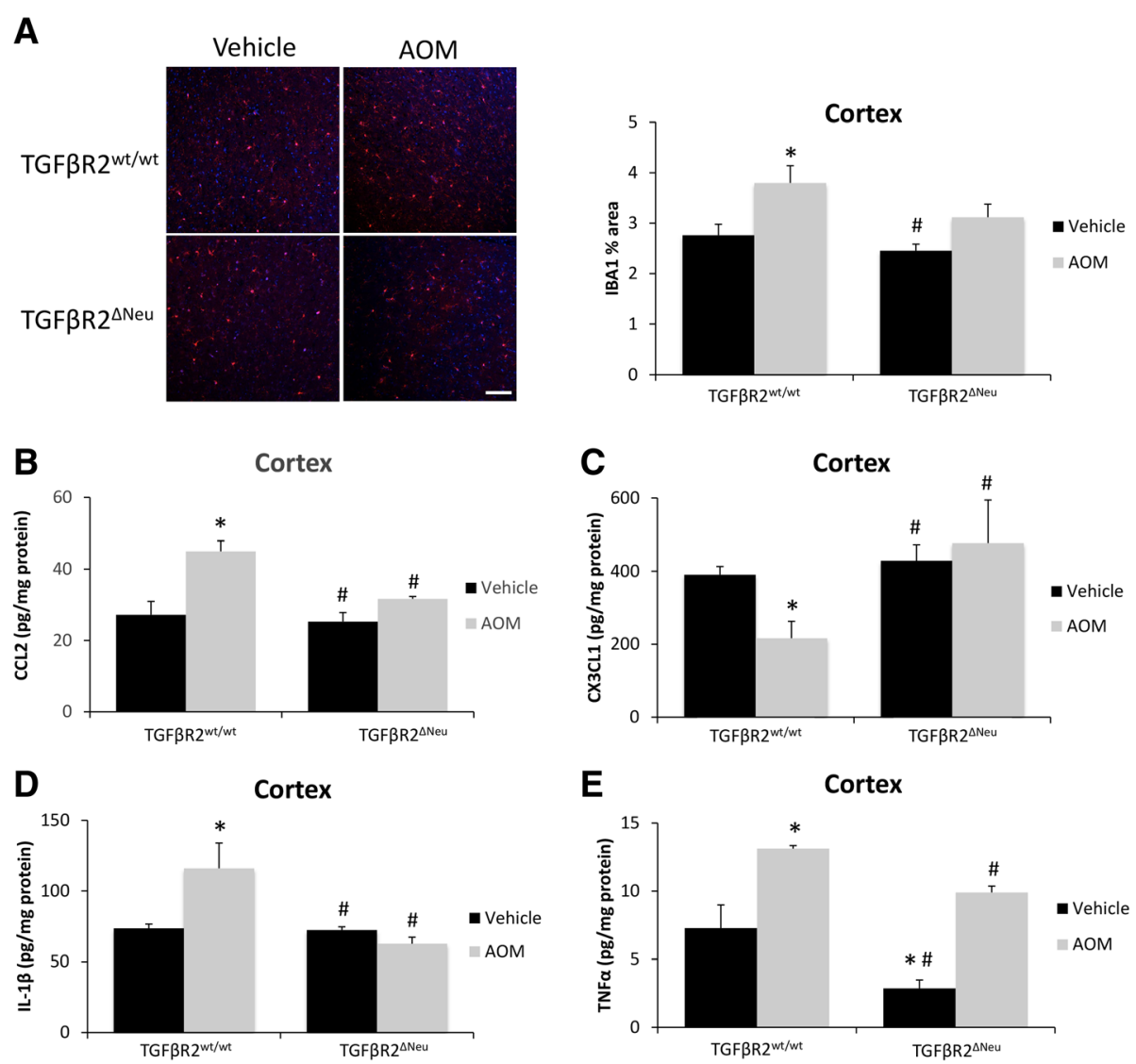

Fig. 5 Neuroinflammation during AOM-induced HE is driven by TGFBR2 in neurons. a Representative staining and quantification for IBA1 (red) in the cortex from of TGF $\beta R 2^{\text {wt } / w t}$ and TGF $\beta R 2^{\Delta N e u}$ mice administered vehicle or AOM. DAPI (blue) was used to stain nuclei. Scale bar indicates $75 \mu M$. b CCL2 protein expression normalized by total protein concentration in the cortex of TGF $\beta R 2^{\text {wt }} / \mathrm{wt}$ and TGF $\beta R 2^{\triangle \mathrm{Neu}}$ mice administered vehicle or AOM. c CX3CL1 protein expression normalized by total protein concentration in the cortex of TGF $\beta R 2^{\text {wt } / w t}$ and TGF $\beta R 2^{\triangle N \text { Neu }}$ mice administered vehicle or AOM. $\mathbf{d}$ IL-1 $\beta$ protein expression normalized by total protein concentration in the cortex of TGF $\beta R 2^{\text {wt } / w t}$ and TGF $\beta R 2^{\triangle N \text { Neu }}$ mice administered vehicle or AOM. e TNFa protein expression normalized by total protein concentration in the cortex of TGF $\beta R 2^{\text {wt }} / \mathrm{wt}$ and TGF $\beta R 2^{\Delta \mathrm{Neu}}$ mice administered vehicle or $A O M$. ${ }^{*} p<0.05$ compared to TGF $\beta R 2^{\text {wt }}{ }^{\text {wt }}$ vehicle-treated mice, ${ }^{\#} p<0.05$ compared to TGF $\beta R 2^{\text {wt }}{ }^{\text {wt }}$ AOM-treated mice. $n=3$ for all analyses

significant differences between the groups from 16 to $22 \mathrm{~h}$ after AOM injection (Fig. 4a). AOM-treated TGF $\beta R 2^{\triangle \mathrm{Neu}}$ mice had a significantly greater latency in progression to coma compared to AOM-treated TGF $\beta R 2^{\text {wt } / \text { wt }}$ mice (Fig. 4b). Not surprisingly, there was no change in liver pathology as hepatocyte necrosis, and microvesicular steatosis was present in AOM-treated TGF $\beta R 2^{\text {wt/wt }}$ and TGF $\beta R 2^{\triangle \mathrm{Neu}}$ mice (Fig. 4c). These findings are supported by serum chemistry analyses as ALT (Fig. 4d) and AST (Fig. 4e) are significantly increased in both TGF $\beta R 2^{\mathrm{wt} / \mathrm{wt}}$ and TGF $\beta R 2^{\triangle \mathrm{Neu}}$ mice administered AOM with no significant differences between these two groups.

Genetic deletion of neuronal TGF $\beta R 2$ could influence neuroinflammation during AOM-induced $\mathrm{HE}$, influencing neurological decline. Microglia proliferation in the cortex was significantly increased in AOM-treated TGF $\beta R 2^{\mathrm{wt} / \mathrm{wt}}$ mice compared to vehicle-treated TGF $\beta R 2^{\mathrm{wt} / \mathrm{wt}}$ mice, though this increase was not observed in TGF $\beta R 2^{\triangle \mathrm{Neu}}$ mice treated with AOM (Fig. 5a). The pro-inflammatory chemokine CCL2 was significantly increased in the cortex of TGF $\beta R 2^{\mathrm{wt} / \mathrm{wt}}$ AOM-treated mice compared to vehicle-treated TGF $\beta R 2^{\text {wt/wt }}$ mice, with TGF $\beta R 2^{\triangle \mathrm{Neu}}$ AOM-treated mice having no significant change compared to vehicle-treated TGF $\beta R 2^{\text {wt/wt }}$ mice (Fig. 5b). The anti-inflammatory chemokine CX3CL1 was significantly decreased in the cortex of TGF $\beta R 2^{\mathrm{wt} / \mathrm{wt}}$ AOM-treated mice, but not in TGF $\beta R 2^{\triangle \mathrm{Neu}}$ AOM-treated mice, when both groups were compared to vehicle-treated TGF $\beta R 2^{\mathrm{wt} / \mathrm{wt}}$ mice, (Fig. $5 \mathrm{c}$ ). The pro-inflammatory cytokines IL-1 $\beta$ (Fig. 5d) and TNF $\alpha$ (Fig. 5e) were significantly increased in the cortex of TGF $\beta R 22^{\mathrm{wt} / \mathrm{wt}}$ AOM-treated mice when compared to vehicle-treated TGF $\beta R 2^{\mathrm{wt} / \mathrm{wt}}$ mice, with TGF $\beta R 2^{\triangle \mathrm{Neu}}$ AOM-treated mice having no significant increase of either cytokine compared to TGF $\beta R 2^{\mathrm{wt} / \mathrm{wt}}$ vehicle-treated mice. Therefore, genetic ablation of TGF $\beta R 2$ in neurons 


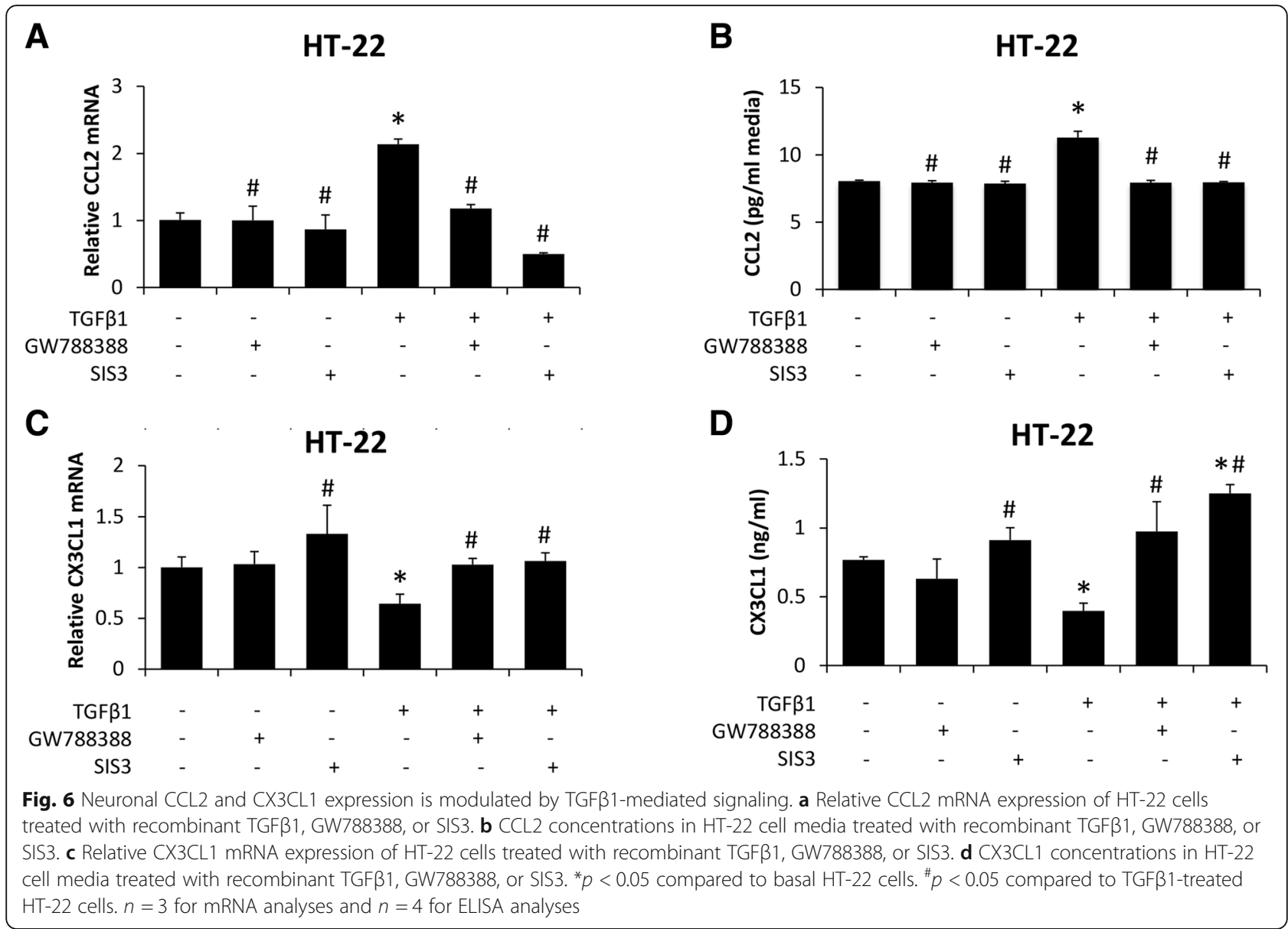

reduced neurological decline and neuroinflammation in AOM-treated mice.

\section{Neuroinflammatory response induced by TGF 1 is dependent upon TGF $\beta$ receptor and SMAD3-dependent signaling}

Due to TGF $\beta R 2^{\triangle N e u}$ mice being protected from AOM-induced neurological decline and having reduced neuroinflammation compared to TGF $\beta \mathrm{R} 2^{\mathrm{wt} / \mathrm{wt}}$ mice, the mechanisms that lead to the reduced neuroinflammatory response are important to identify. As the activation of microglia can be driven by increased neuronal CCL2 and decreased neuronal CX3CL1 secretion [10, $11,26,27]$, the influence of TGF $\beta 1$ on this process was examined in neurons. HT-22 cells were treated with TGF $\beta 1$, the TGF $\beta$ receptor antagonist GW788388, and the SMAD3 inhibitor SIS3. TGF $\beta 1$ treatment alone significantly induced CCL2 mRNA expression (Fig. 6a) and secretion into media (Fig. 6b) compared to basal HT-22 cells, and these effects were significantly inhibited by treatment with GW788388 or SIS3. CX3CL1 mRNA expression (Fig. 6c) and secretion into media (Fig. 6d) were significantly reduced by treatment with
TGF $\beta 1$ alone in comparison to basal HT-22 cells, and levels were restored to near basal levels if TGF $\beta 1$-treated HT-22 cells were co-treated with GW788388 or SIS3.

In order to demonstrate that these changes in chemokine expression and secretion would influence microglia activation, conditioned media from HT-22 cells were added to EOC-20 cells, a microglia cell line. Treatment of EOC-20 cells with conditioned media from TGF $\beta 1$-treated HT-22 cells increased IL-1 $\beta$ (Fig. 7a) and TNF $\alpha$ mRNA expression (Fig. 7b) when compared to EOC-20 cells supplemented with basal HT-22 conditioned media. In addition, phagocytosis activity (Fig. 7c) was induced in EOC-20 cells supplemented with conditioned media from TGF $\beta 1$-treated HT-22 cells compared to EOC-20 cells supplemented with basal-conditioned media from HT-22 cells. These effects of TGF $\beta 1$-conditioned media were not observed in conditioned media from HT-22 cells treated with TGF $\beta 1$ and GW788388 or TGF $\beta 1$ and SIS3 when compared to EOC-20 cells supplemented with basal-conditioned media from HT-22 cells. Together, these data support that TGF $\beta R 2$ and SMAD3 inhibition in neurons changes the constituents 


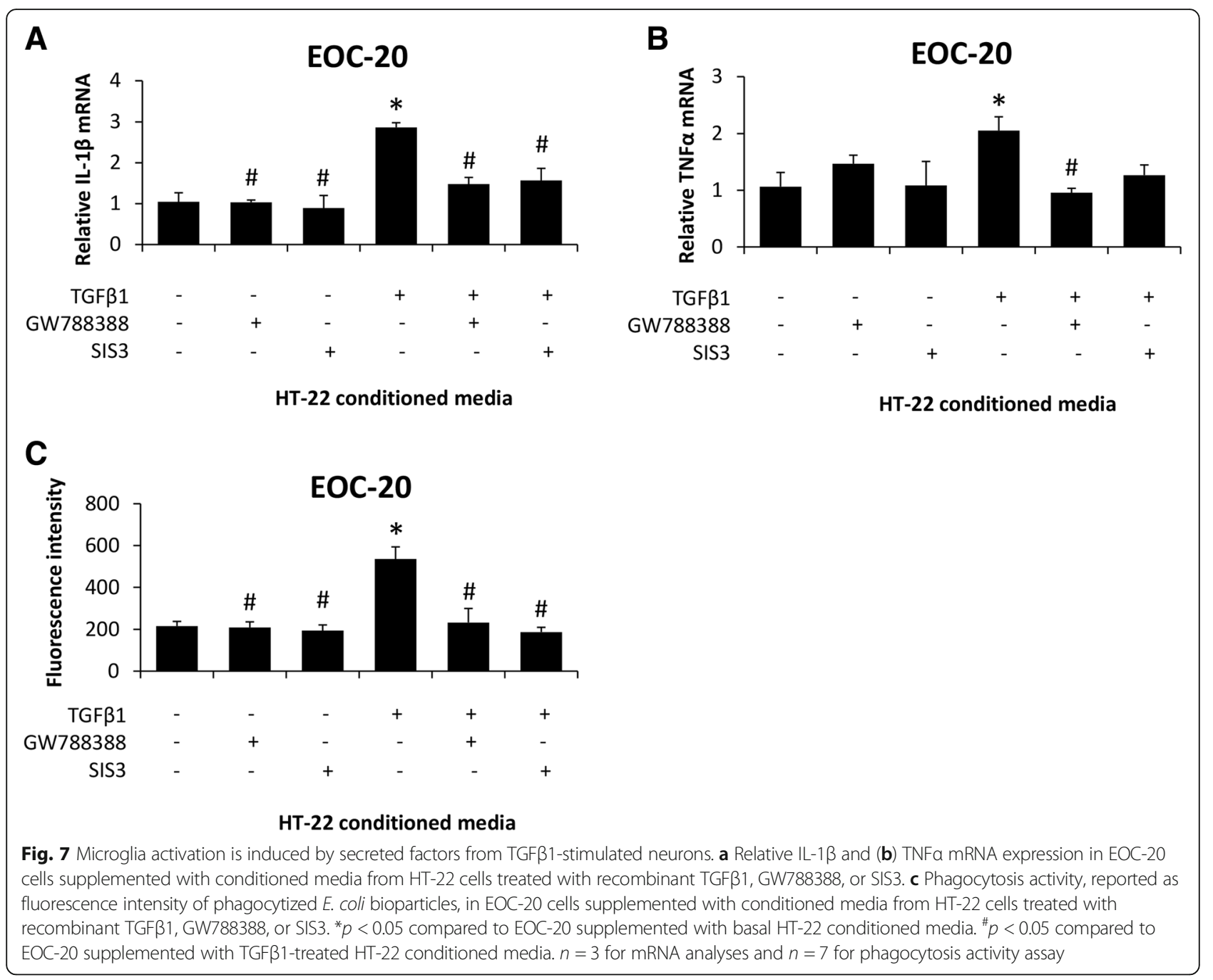

of the conditioned media to inhibit neuroinflammation and phagocytosis.

To ensure this was due to changes in CCL2, antagonists to chemokine receptor 2 (INCB) or chemokine receptor 4 (C021) were added to EOC-20 cells supplemented with conditioned media from TGF $\beta 1$-treated HT-22 cells. In parallel, CX3CL1 was added into EOC-20 cells supplemented with TGF $\beta 1$-treated HT-22 conditioned media. In EOC-20 cells, IL-1 $\beta$ mRNA expression (Fig. 8a), TNF $\alpha$ mRNA expression (Fig. 8b), and phagocytosis (Fig. 8c) were induced by TGF $\beta 1$-conditioned media from HT-22 cells, and these effects were not present following the treatment with INCB or C021 as well as following the supplementation of CX3CL1 when all groups were compared to EOC-20 cells supplemented with basal-conditioned media from HT-22 cells. Together, these data support that TGF $\beta 1$ increases CCL2 and decreases CX3CL1 secretion in neurons, which directly stimulates neuroinflammation and phagocytosis activity in microglia.

\section{Discussion}

The data presented here indicates that TGF $\beta 1$ plays a role in the pathogenesis of $\mathrm{HE}$ by inducing microglia activation and neuroinflammation. TGF $\beta 1$ is released into the circulation after acute liver failure and binds TGF $\beta R 2$ in neurons, resulting in increased CCL2 expression and decreased CX3CL1 expression leading to microglial activation. A summary of this disease process is provided as a working model (Fig. 9). Strategies that decrease circulating TGF $\beta 1$ or antagonize neuronal TGF $\beta 22$ may be effective therapeutic options for the management of HE.

We have previously demonstrated that hepatic TGF $\beta 1$ expression is upregulated in the AOM model of acute liver failure [12], which is consistent with other studies in response to a variety of hepatotoxins [28, 29]. During acute liver failure in patients due to acetaminophen toxicity, increased levels of hepatic TGF $\beta 1$ mRNA expression and circulating TGF $\beta 1$ levels have been observed when compared to healthy controls [30]. In the current study, we observed 


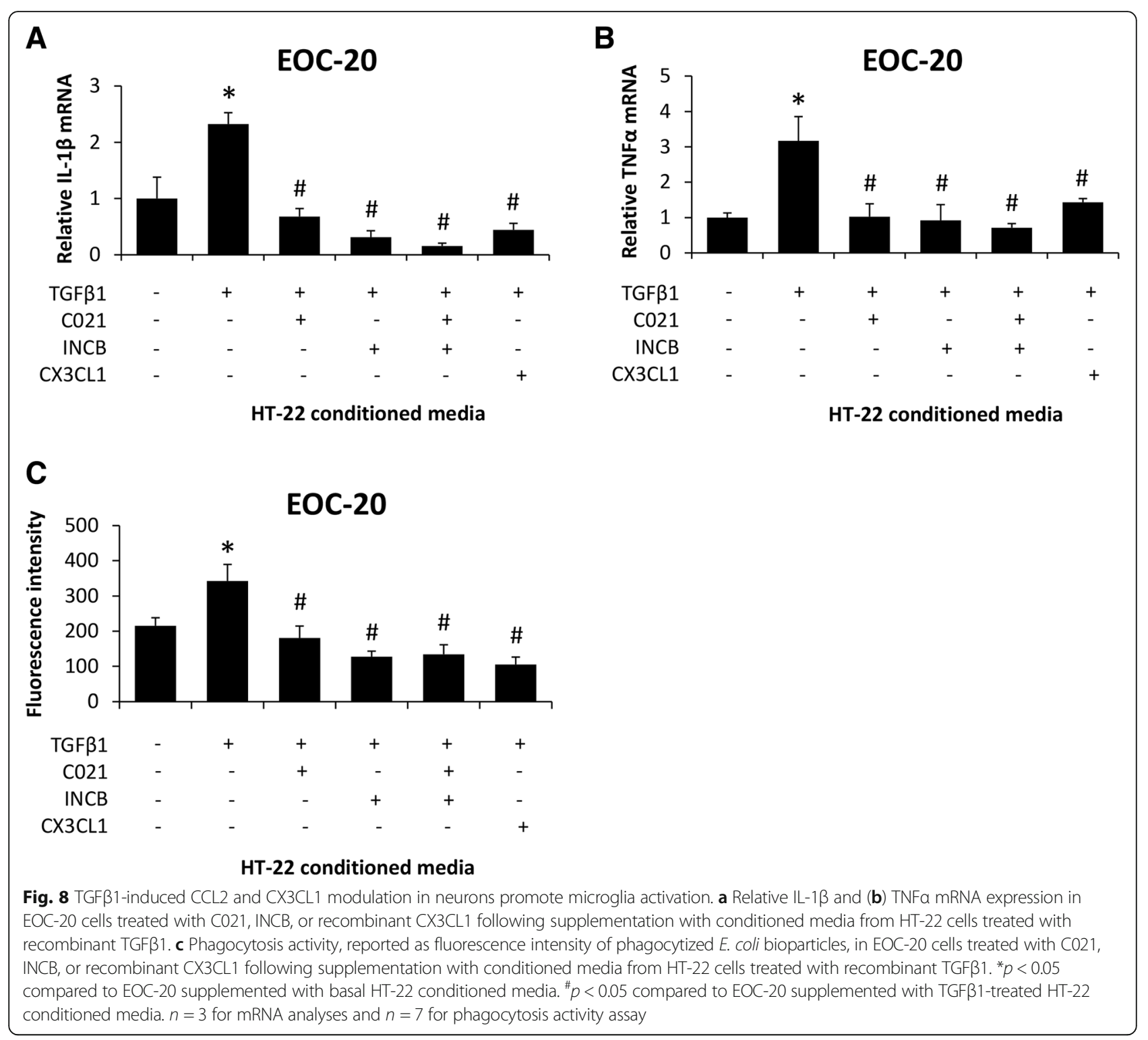

increased TGF $\beta 1$ expression localized primarily to hepatocyte populations due to its co-localization with CK8, supporting findings from our previous work demonstrating TGF $\beta 1$ co-localization> with albumin during AOM-induced liver failure [12]. Possible consequences of TGF $\beta 1$ signaling in hepatocytes may range from induction of apoptotic pathways [31] to the inhibition of hepatocyte proliferation and liver regeneration [29]. In the current study, we have demonstrated that anti-TGF $\beta 1$ treatment had similar liver pathology after injection of AOM compared to IgG1 control mice, but had protective effects on the neurological complications associated with acute liver failure. These data suggest that while hepatic TGF $\beta 1$ expression and circulating TGF $\beta 1$ levels are increased in response to AOM-induced liver injury, this cytokine has minimal involvement in the subsequent hepatocyte apoptotic/regeneration pathways in this model. These observations are not surprising given that AOM-induced liver injury is predominantly due to hepatocyte necrosis, rather than apoptosis, with minimal regeneration occurring [5, 32], offering a unique model of liver injury allowing for the dissection of hepatocyte versus neurological actions of TGF $\beta 1$.

The data presented here suggest that increased circulating TGF $\beta 1$ following AOM-induced hepatic necrosis is influencing neurological function and neuroinflammation during acute liver failure. The concept that systemic inflammatory signals can induce neuroinflammation is not without precedent in that microglia activation and astrogliosis have been observed in many models of 


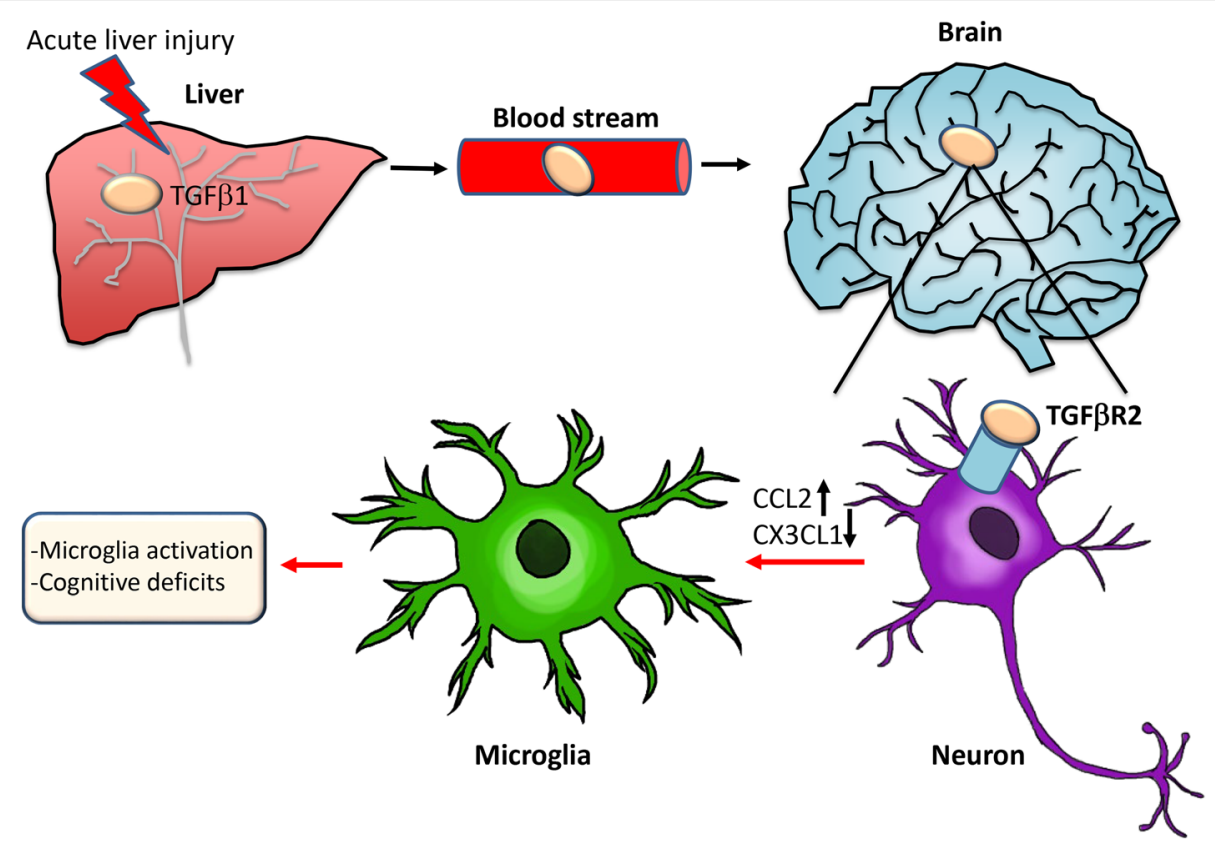

Fig. 9 Working model of TGF $\beta 1$ signaling during AOM-induced HE. AOM-induced liver failure leads to an increase of hepatic TGF $\beta 1$ that enters the bloodstream, crosses the blood-brain barrier, and enters the brain. This results in the activation of TGF $\beta R 2$ on neurons leading to increased expression and secretion of CCL2 and decreased expression and secretion of CX3CL1 from neurons. This imbalance of CCL2 and CX3CL1 leads to changes in chemokine receptor-mediated signaling in microglia, which ultimately results in microglia activation and worse HE outcomes

systemic inflammation [33-36], although the mechanism by which this occurs is uncertain. In the AOM model, we observe increased circulating TGF $\beta 1$ expression following liver injury. In previous studies, we found increased TGF $\beta 1$ protein expression in the cortex without a subsequent increase of mRNA expression [12], which supports that systemic increases of TGF $\beta 1$ lead to elevated TGF $\beta 1$ levels in the brain. While we do observe increased levels of TGF $\beta 1$ in the blood, it is not known whether this is free TGF $\beta 1$, TGF $\beta 1$ bound to plasma proteins, or TGF $\beta 1$ present in extracellular vesicles. One possible mechanism for the induction of neuroinflammation by TGF $\beta 1$ is through circulating exosomes [34]. Indeed, exosomes isolated from the bloodstream in a mouse model of endotoxemia contained many inflammatory microRNAs and cytokines that induced systemic inflammation and neuroinflammation when injected into a naïve mouse [34]. Given that TGF $\beta 1$ can be packaged into exosomes [37, 38], it is conceivable that the systemic TGF $\beta 1$ observed in our model of acute liver failure may be delivered via exosomes. Regardless of the mechanism of delivery, for circulating TGF $\beta 1$ to influence neuroinflammation, TGF $\beta 1$ has to cross the blood-brain barrier. During the pathogenesis of HE, the blood-brain barrier becomes hyper-permeable to many molecules $[39,40]$. Indeed, we have demonstrated that TGF $\beta 1$ itself is able to induce hyperpermeability of the blood-brain barrier during acute liver failure via the induction of matrix metalloproteinase- 9 expression in brain endothelial cells and the alteration of tight junction protein expression [13]. Therefore, the strong effects observed as a result of increased TGF $\beta 1$ signaling regarding neuroinflammation during AOM-induced HE may partially result from the entry of other signaling mediators and metabolites, like bile acids, into the brain.

TGF $\beta 1$ signaling in the brain, similar to other organs, can be pro- or anti-inflammatory depending upon the disease state [41-44]. For example, TGF $\beta 1$ inhibits microglia chemotaxis towards amyloid beta aggregates observed in Alzheimer's disease via activation of TGF $\beta R / S M A D-2$-mediated downregulation of the chemokine CCL5 [41]. Conversely, TGF $\beta 1$ signaling via TGF $\beta$ R/SMAD-2/3 activation is pro-inflammatory in the context of mild traumatic brain injury [44]. In vitro studies using primary mouse and rat microglia treated with rTGF $\beta 1$ find differential effects on physiology and gene expression [45]. The proliferation of microglia was stimulated by TGF $\beta 1$ treatment in rat microglia but not mouse microglia [45]. In addition, cytokine profiles were changed in mouse microglia in response to TGF $\beta 1$ but were not consistent with the anti-inflammatory cytokine IL-10 being upregulated while the anti-inflammatory peroxisome proliferator-activated receptor gamma was downregulated [45]. The data presented in the current 
study support a role for TGF $\beta 1$ in microglia activation and the subsequent neuroinflammatory processes. That being said, these findings may not translate into chronic models of $\mathrm{HE}$ and further studies are necessary to fully characterize the role of TGF $\beta 1$ signaling with neuroinflammation during HE.

We have previously demonstrated that CCL2 expression and secretion from neurons is central to the activation of microglia and subsequent pro-inflammatory cascade in the brain during acute liver failure [10]. Furthermore, we have previously demonstrated that TGF $\beta R 2$ expression is found predominantly in neurons in the brain and that TGF $\beta$ signaling increases the activation of SMAD3 in neurons during acute liver failure [12]. In the current study, we present novel data indicating that neuron-specific knockout of TGF $\beta R 2$ attenuated the expression of CCL2, increased CX3CL1 expression, inhibited microglia activation, and reduced neurological deficits during acute liver failure. These observations are consistent with previous studies using models of inflammation in the liver and other organs $[11,15,46-48]$. In vitro studies determined that TGF $\beta 1$ led to increased CCL2 and decreased CX3CL1 secretion for HT-22 cells, and this resulted in a direct increase of a neuroinflammatory response for EOC-20 cells, supporting the in vivo findings of this study. That being said, the role of astrocytes in neuroinflammation during AOM-induced HE was not investigated, and these cells could play a contributing role in this process. In human astrocytes stimulated with IL-1 $\beta$ and TNF $\alpha$, the same cytokines we show upregulated in the cortex of our AOM-treated mice; 14 chemokines/ cytokines were upregulated while 2 were downregulated [49]. Therefore, even though our manipulations were primarily targeted to TGF $\beta R 2$ activity on neurons, it is possible that astrocytes contribute to these results.

\section{Conclusions}

In summary, the data presented here suggest that during acute liver failure, TGF $\beta 1$ expression is increased in the liver, contributing to increased circulating TGF $\beta 1$, which in turn regulates the neuroinflammation and neurological deficits associated with HE. Strategies to neutralize TGF $\beta 1$ in the bloodstream and inhibit neuronal TGF $\beta R 2$ activity are able to attenuate the development of $\mathrm{HE}$ without significantly altering the underlying liver damage in this model of HE. Together, these data suggest that TGF $\beta 1$ may be a central pro-inflammatory mediator contributing to neurological impairment during HE, and strategies to target TGF $\beta 1$ signaling may be a viable target for the development of novel adjunct therapies for the management of $\mathrm{HE}$.

\section{Additional file}

Additional file 1: Supplementary Materials and Methods. Table S1. Primers used for PCR. Supplementary Results. Figure S1. Validation of TGF $\beta R 2^{\text {wt }} /$ wt as appropriate HE controls. Figure S2. Immunofluorescence images for DAPI and YFP in TGF $\beta R 2^{\text {wt/wt }}$ and TGF $\beta R 2^{\triangle \mathrm{Neu}}$ cortex. (DOCX $3171 \mathrm{~kb})$

\section{Abbreviations}

ALT: Alanine aminotransferase; Anti-TGFß1: Neutralizing antibodies against TGFß1; AOM: Azoxymethane; AST: Aspartate aminotransferase; C021: C 021 dihydrochloride; CCL2: Chemokine ligand 2; CX3CL1: C-X3-C motif ligand 1; DAPI: 4',6-diamidino-2-phenylindole; GAPDH : Glyceraldehyde 3-phosphate dehydrogenase; HE: Hepatic encephalopathy; IgG1: Immunoglobulin G1; IL-1ß: Interleukin-1 beta; INCB: INCB 3284 dimesylate; TGF $\beta$ : Transforming growth factor beta; TGF $\beta R 2$ : Transforming growth factor beta receptor 2; TNFa: Tumor necrosis factor alpha

\section{Acknowledgements}

This work was completed with support from the Veterans Health Administration and with resources and the use of facilities at the Central Texas Veterans Health Care System, Temple, Texas. The contents do not represent the views of the U.S. Department of Veterans Affairs or the United States Government.

\section{Funding}

This study was funded by NIH R01 awards (DK082435 and DK112803) and a VA Merit award (BX002638) from the United States Department of Veterans Affairs Biomedical Laboratory Research and Development Service to Dr. DeMorrow. This study was also funded by a VA Career Development award (BX003486) from the United States Department of Veterans Affairs Biomedical Laboratory Research and Development Service to Dr. McMillin.

\section{Availability of data and materials}

The datasets used and/or analyzed for the current study are available from the corresponding author upon reasonable request.

\section{Authors' contributions}

$M M, S G, G F, A P, E W, B J, A T, A B$, and SD performed the experiments and data analysis. MM, SG, GF, and SD performed the animal experiments and tissue collection. MM and SD formulated the study and wrote the manuscript. All authors critically edited and approved the final manuscript.

\section{Ethics approval and consent to participate}

All animal experiments in this study were performed in accordance with the Animal Welfare Act, and the Guide for the care and use of Laboratory Animals, and were approved by the Baylor Scott \& White Health IACUC committee (\#2011-052R).

\section{Consent for publication}

Not applicable.

\section{Competing interests}

The authors declare that they have no competing interests.

\section{Publisher's Note}

Springer Nature remains neutral with regard to jurisdictional claims in published maps and institutional affiliations.

\section{Author details}

${ }^{1}$ Central Texas Veterans Health Care System, Temple, TX, USA. ²Department of Medical Physiology, College of Medicine, Texas A\&M University Health Science Center, Temple, TX, USA. ${ }^{3}$ Division of Pharmacology and Toxicology, College of Pharmacy, The University of Texas at Austin, Austin, TX, USA. ${ }^{4}$ Department of Internal Medicine, Dell Medical School, The University of Texas at Austin, Austin, TX, USA. 


\section{Received: 25 October 2018 Accepted: 18 March 2019} Published online: 02 April 2019

\section{References}

1. Kaplowitz N. Drug-induced liver disorders: implications for drug development and regulation. Drug Saf. 2001;24(7):483-90.

2. American Association for the Study of Liver D, European Association for the Study of the L. Hepatic encephalopathy in chronic liver disease: 2014 practice guideline by the European Association for the Study of the liver and the American Association for the Study of Liver Diseases. J Hepatol. 2014:61(3):642-59.

3. Bernal W, Auzinger G, Dhawan A, Wendon J. Acute liver failure. Lancet. 2010;376(9736):190-201.

4. Hazell AS, Butterworth RF. Hepatic encephalopathy: an update of pathophysiologic mechanisms. Proc Soc Exp Biol Med. 1999;222(2):99-112.

5. Matkowskyj KA, Marrero JA, Carroll RE, Danilkovich AV, Green RM, Benya RV. Azoxymethane-induced fulminant hepatic failure in C57BL/6J mice: characterization of a new animal model. Am J Phys. 1999;277(2):G455-62.

6. Sato K, Arai N, Omori A, Hida A, Kimura A, Takeuchi S. Hyperammonaemia and associated factors in unprovoked convulsive seizures: a cross-sectional study. Seizure. 2016;43:6-12.

7. Rodrigo R, Cauli O, Gomez-Pinedo U, Agusti A, Hernandez-Rabaza V, GarciaVerdugo JM, et al. Hyperammonemia induces neuroinflammation that contributes to cognitive impairment in rats with hepatic encephalopathy. Gastroenterology. 2010;139(2):675-84.

8. Balzano T, Dadsetan S, Forteza J, Cabrera-Pastor A, Taoro-Gonzalez L, Malaguarnera $\mathrm{M}$, et al. chronic hyperammonemia induces peripheral inflammation that leads to cognitive impairment in rats: reversal by anti-tnfa treatment. J Hepatol. 2019. https://doi.org/10.1016/j.jhep.2019.01.008. [Epub ahead of print].

9. Butterworth RF. Hepatic encephalopathy: a central neuroinflammatory disorder? Hepatology. 2011;53(4):1372-6.

10. McMillin M, Frampton G, Thompson M, Galindo C, Standeford H, Whittington E, et al. Neuronal CCL2 is upregulated during hepatic encephalopathy and contributes to microglia activation and neurological decline. J Neuroinflammation. 2014;11:121.

11. McMillin M, Grant S, Frampton G, Andry S, Brown A, DeMorrow S. Fractalkine suppression during hepatic encephalopathy promotes neuroinflammation in mice. J Neuroinflammation. 2016;13(1):198.

12. McMillin M, Galindo C, Pae HY, Frampton G, Di Patre PL, Quinn M, et al. Gli1 activation and protection against hepatic encephalopathy is suppressed by circulating transforming growth factor beta1 in mice. J Hepatol. 2014;61(6):1260-6.

13. McMillin MA, Frampton GA, Seiwell AP, Patel NS, Jacobs AN, DeMorrow S. TGFbeta1 exacerbates blood-brain barrier permeability in a mouse model of hepatic encephalopathy via upregulation of MMP9 and downregulation of claudin-5. Lab Investig. 2015;95(8):903-13.

14. Silva VR, Secolin R, Vemuganti R, Lopes-Cendes I, Hazell AS. Acute liver failure is associated with altered cerebral expression profiles of long noncoding RNAs. Neurosci Lett. 2017;656:58-64.

15. McMillin M, Frampton G, Grant S, Khan S, Diocares J, Petrescu A, et al. Bile acid-mediated Sphingosine-1-phosphate receptor 2 signaling promotes Neuroinflammation during hepatic encephalopathy in mice. Front Cell Neurosci. 2017;11:191.

16. Popek M, Bobula B, Sowa J, Hess G, Polowy R, Filipkowski RK, et al. Cortical synaptic transmission and plasticity in acute liver failure are decreased by presynaptic events. Mol Neurobiol. 2018;55(2):1244-58.

17. Chastre A, Belanger M, Nguyen BN, Butterworth RF. Lipopolysaccharide precipitates hepatic encephalopathy and increases blood-brain barrier permeability in mice with acute liver failure. Liver Int. 2014;34(3):353-61.

18. Grant $S$, McMillin M, Frampton $G$, Petrescu AD, Williams $E$, Jaeger $V$, et al. Direct comparison of the thioacetamide and azoxymethane models of type a hepatic encephalopathy in mice. Gene Expr. 2018;18(3):171-85.

19. McMillin M, Frampton G, Tobin R, Dusio G, Smith J, Shin H, et al. TGR5 signaling reduces neuroinflammation during hepatic encephalopathy. J Neurochem. 2015;135(3):565-76.

20. McMillin M, Galindo C, Pae HY, Frampton G, Di Patre P, Quinn M, et al. Gli1 activation and protection against hepatic encephalopathy is suppressed by circulating transforming growth factor $\beta 1$ in mice. J Hepatol. 2014;61(6):1260-6.
21. Li Y, Maher P, Schubert D. A role for 12-lipoxygenase in nerve cell death caused by glutathione depletion. Neuron. 1997;19(2):453-63.

22. Schafer M, Goodenough S, Moosmann B, Behl C. Inhibition of glycogen synthase kinase 3 beta is involved in the resistance to oxidative stress in neuronal HT22 cells. Brain Res. 2004;1005(1-2):84-9.

23. Frampton $G$, Invernizzi P, Bernuzzi F, Pae HY, Quinn M, Horvat D, et al. Interleukin-6-driven progranulin expression increases cholangiocarcinoma growth by an Akt-dependent mechanism. Gut. 2012;61(2):268-77.

24. DeMorrow S, Francis H, Gaudio E, Venter J, Franchitto A, Kopriva S, et al. The endocannabinoid anandamide inhibits cholangiocarcinoma growth via activation of the noncanonical Wnt signaling pathway. Am J Physiol Gastrointest Liver Physiol. 2008;295(6):G1150-8.

25. Livak KJ, Schmittgen TD. Analysis of relative gene expression data using real-time quantitative $P C R$ and the 2(-Delta Delta $C(T))$ method. Methods. 2001:25(4):402-8.

26. Harrison JK, Jiang Y, Chen S, Xia Y, Maciejewski D, McNamara RK, et al. Role for neuronally derived fractalkine in mediating interactions between neurons and CX3CR1-expressing microglia. Proc Natl Acad Sci U S A. 1998;95(18):10896-901.

27. Selenica ML, Alvarez JA, Nash KR, Lee DC, Cao C, Lin X, et al. Diverse activation of microglia by chemokine (C-C motif) ligand 2 overexpression in brain. J Neuroinflammation. 2013;10:86

28. Leu II, Crissey MA, Taub R. Massive hepatic apoptosis associated with TGF-beta1 activation after Fas ligand treatment of IGF binding protein-1-deficient mice. J Clin Invest. 2003;111(1):129-39.

29. Nozato E, Shiraishi M, Nishimaki T. Up-regulation of hepatocyte growth factor caused by an over-expression of transforming growth factor beta, in the rat model of fulminant hepatic failure. J Surg Res. 2003: 115(2):226-34.

30. Miwa Y, Harrison PM, Farzaneh F, Langley PG, Williams R, Hughes RD. Plasma levels and hepatic mRNA expression of transforming growth factor-beta1 in patients with fulminant hepatic failure. J Hepatol. 1997;27(5):780-8.

31. Fang $D, H e Y$, Luan Z. Simvastatin augments activation of liver regeneration through attenuating transforming growth factor-beta1 induced-apoptosis in obstructive jaundice rats. Exp Ther Med. 2017; 14(5):4839-45.

32. Belanger M, Cote J, Butterworth RF. Neurobiological characterization of an azoxymethane mouse model of acute liver failure. Neurochem Int. 2006; 48(6-7):434-40

33. Falck M, Osredkar D, Wood TR, Maes E, Flatebo T, Sabir H, et al. Neonatal systemic inflammation induces inflammatory reactions and brain apoptosis in a pathogen-specific manner. Neonatology. 2018;113(3):212-20.

34. Li JJ, Wang B, Kodali MC, Chen C, Kim E, Patters BJ, et al. In vivo evidence for the contribution of peripheral circulating inflammatory exosomes to neuroinflammation. J Neuroinflammation. 2018;15(1):8.

35. Hamasaki MY, Machado MCC, Pinheiro da Silva F. Animal models of neuroinflammation secondary to acute insults originated outside the brain. J Neurosci Res. 2018:96(3):371-8.

36. Patra A, Huang H, Bauer JA, Giannone PJ. Neurological consequences of systemic inflammation in the premature neonate. Neural Regen Res. 2017: 12(6):890-6.

37. Cobb DA, Kim OK, Golden-Mason L, Rosen HR, Hahn YS. Hepatocyte-derived exosomes promote $T$ follicular regulatory cell expansion during hepatitis $C$ virus infection. Hepatology. 2018;67(1):71-85.

38. Yen EY, Miaw SC, Yu JS, Lai IR. Exosomal TGF-beta1 is correlated with lymphatic metastasis of gastric cancers. Am J Cancer Res. 2017;7(11):2199-208.

39. McMillin M, Frampton G, Quinn M, Ashfaq S, de los Santos M 3rd, Grant S, et al. Bile acid signaling is involved in the neurological decline in a murine model of acute liver failure. Am J Pathol. 2016;186(2):312-23.

40. Lockwood AH, Yap EW, Wong WH. Cerebral ammonia metabolism in patients with severe liver disease and minimal hepatic encephalopathy. J Cereb Blood Flow Metab. 1991;11(2):337-41.

41. Huang WC, Yen FC, Shie FS, Pan CM, Shiao YJ, Yang CN, et al. TGF-beta1 blockade of microglial chemotaxis toward Abeta aggregates involves SMAD signaling and down-regulation of CCL5. J Neuroinflammation. 2010;7:28.

42. Li Y, Shen XZ, Li L, Zhao TV, Bernstein KE, Johnson AK, et al. Brain transforming growth factor-beta resists hypertension via regulating microglial activation. Stroke. 2017:48(9):2557-64.

43. Taylor RA, Chang CF, Goods BA, Hammond MD, Mac Grory B, Ai Y, et al. TGF-beta1 modulates microglial phenotype and promotes recovery after intracerebral hemorrhage. J Clin Invest. 2017;127(1):280-92. 
44. Patel RK, Prasad N, Kuwar R, Haldar D, Abdul-Muneer PM. Transforming growth factor-beta 1 signaling regulates neuroinflammation and apoptosis in mild traumatic brain injury. Brain Behav Immun. 2017;64:244-58.

45. Lively S, Lam D, Wong R, Schlichter LC. Comparing effects of transforming growth factor beta1 on microglia from rat and mouse: transcriptional profiles and potassium channels. Front Cell Neurosci. 2018;12:115.

46. Mutoh H, Sashikawa M, Hayakawa H, Sugano K. Monocyte chemoattractant protein-1 is generated via TGF-beta by myofibroblasts in gastric intestinal metaplasia and carcinoma without H. Pylori infection. Cancer Sci. 2010;101(8):1783-9.

47. Wan M, Li C, Zhen G, Jiao K, He W, Jia X, et al. Injury-activated transforming growth factor beta controls mobilization of mesenchymal stem cells for tissue remodeling. Stem Cells. 2012;30(11):2498-511.

48. Zhang L, Tan J, Jiang X, Qian W, Yang T, Sun X, et al. Neuron-derived CCL2 contributes to microglia activation and neurological decline in hepatic encephalopathy. Biol Res. 2017;50(1):26.

49. Choi SS, Lee HJ, Lim I, Satoh J, Kim SU. Human astrocytes: secretome profiles of cytokines and chemokines. PLoS One. 2014;9(4):e92325.

Ready to submit your research? Choose BMC and benefit from:

- fast, convenient online submission

- thorough peer review by experienced researchers in your field

- rapid publication on acceptance

- support for research data, including large and complex data types

- gold Open Access which fosters wider collaboration and increased citations

- maximum visibility for your research: over $100 \mathrm{M}$ website views per year

At $\mathrm{BMC}$, research is always in progress.

Learn more biomedcentral.com/submissions 